\title{
Developing a Model for Reference Research Statistics
}

Applying the "Warner Model" of Reference Question Classification to Streamline Research Services

The merger of an academic library with the main branch of a large city's public library in 2003 required a new method for determining customer-patron transactions. The Warner model, previously reported in RUSQ in 2001, was adopted and used to investigate the possibilities for developing tiered reference, adjusting staffing levels, and improving service in a merged reference unit. The adopted model is recommended to other libraries that want to develop effective tools for analyzing reference services.

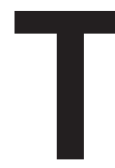

he new Dr. Martin Luther King Jr. (MLK) Library, which opened in August 2003, was a collaborative project of the City of San Jose and San Jose State University (SJSU). Two libraries, the University Library of SJSU and the MLK Library-the main branch of the San Jose Public Library (SJPL) systemmerged to create a new entity. The sixyear planning process has been documented on the library's website and in a number of articles, covering the vision of one reference department, the principle of "economies of scale" as they apply to merged units, and creating a collaborative library from two different institutions. ${ }^{1}$ In a broader context, other articles discuss the library as an example in the general discussion of the library as place and consider the implications of how different work and service cultures are brought together in a new institution. ${ }^{2}$

There are merged and unmerged units in the new library. The four merged units in the new library are Access Services (including Circulation), Information Technology, Technical Services, and Reference. Data is gathered in the same way by all public service points, including those that remained unmerged: the public library's Youth Services, General Collections, and the California Room and the SJSU Special Collections unit.

A key element of the planning process dealt with the kind of statistics to be collected to evaluate the library. A comprehensive program of data collection commenced with the opening of the MLK Library in September 2003. The plan involved a number of library services and units, including circulation, collections, computer and study room booking, database usage, donations, financial reports, gate counts, interlibrary services, library services and instruction, website usage, and focus group reports. A consultant, Thomas Childers, was engaged in 2003 to undertake a user and cost analysis aimed at developing benchmarks and to administer two surveys over four years,

\section{Harry C. Meserve, Sandra E. Belanger, Joan Bowlby, and Lisa Rosenblum}

Harry C. Meserve is Associate Librarian, Dr. Martin Luther King Jr. Library, San Jose State University. Sandra E. Belanger is Librarian, Dr. Martin Luther King Jr. Library, San Jose State University (retired). Joan Bowlby is Senior Librarian, Dr. Martin Luther King Jr. Library, San Jose Public Library. Lisa Rosenblum is Director, Hayward (Calif.) Public Library. Submitted for review September 18, 2006; revised and accepted for publication October 15, 2007.

Reference \& User Services Quarterly, vol. 48 , no. 3 , pp. $247-258$

(c) 2009 American Library Association. All rights reserved.

Permission granted to reproduce for nonprofit, educational use. 
one on library facilities and one on library services. A four-person assessment team under the direction of Jo Bell Whitlatch, associate dean of the University Library of SJSU, undertook the evaluation of service delivery, initiated or coordinated a number of service metric studies, and began a workload activity study in 2004. Only results from the assessment of reference and instructional services have been published to date. ${ }^{3}$

\section{LITERATURE REVIEW}

Many articles report the evaluation of reference services through studies of patron satisfaction, patron queuing, reference accuracy, informationseeking behavior, and patron perceptions of reference service. ${ }^{4}$ Methods ranging from observation, unobtrusive testing, time considerations, transaction logs, survey cards, and forms have been used to investigate reference interactions and staffing. ${ }^{5}$ During the planning phase for the MLK Library, the SJSU and SJPL administrations and the Reference and User Services planning committee supported finding a method for evaluating service point activity to facilitate planning, determine levels of business, promote tiered reference models, and address staffing needs. ${ }^{6}$

Whitlatch uses state of the art reference question classification to analyze reference service despite the method's limitations and the need for its categories to be mutually exclusive. ${ }^{7}$ A later survey of methods and forms conducted under the auspices of the Association of Research Libraries suggested that libraries could not agree on methods, models, frequency, or forms; however, the most important data elements were identified as date, type of question, time of day, and location in which the question was asked. ${ }^{8}$

Prior to the library merger, both the university and city libraries had been gathering the statistics required for the SJPL and the California State University systems. For the university library this meant sampling the number of reference transactions only one week out of each semester (in October and March). Initially, every question asked by a patron was simply noted by a slash. Later, academic reference staff and librarians moved to using the letter $R$ for reference questions and the letter $D$ for directional questions. Ciucki's survey of libraries (fifty-seven academic and thirty-two public) on the types of data collected found that while academic libraries kept records by type of question, public libraries gathered written responses. ${ }^{9}$ The task for the combined library was to identify a method acceptable to both institutions.

The question assessment method selected for the MLK Library needed the capacity to sup- port the joint tiered reference service, which was planned to use support staff and student assistants working in partnership with librarians. Courtois's descriptive survey on the use of nonprofessionals in academic libraries is relevant here. Courtois found that 51 percent of responding libraries were using nonprofessionals more, identified four categories of reference queries, and ascertained that 37 percent limited nonprofessionals to answering questions in the first two categories (directional and instructional). The 63 percent of libraries that indicated that nonprofessionals answered questions in all categories also reported that nonprofessionals worked alone during evenings, weekends, and early mornings, when "there is little attempt to formally define the types of questions they should or should not answer." 10

Murfin and Bunge also studied the use of paraprofessionals in academic libraries using the Wisconsin-Ohio Reference Evaluation Program, which employs a two-part form completed by librarians and patrons. Their results show that 20 percent of libraries used paraprofessionals effectively but that 80 percent of libraries found that their use may lower patron success and satisfaction. Effectiveness can be improved when paraprofessionals are encouraged to consult others and are freed from time pressures. ${ }^{11}$

\section{THE WARNER MODEL}

In the context of the MLK Library, Debra Warner's new method for classifying reference questions looked like a promising option. Based on the experience of librarians at the East Carolina University Health Sciences Library, Warner's schema categorized patron reference questions into four levels of increasing complexity, each level designating the kind of activities necessary to answer the question. The four levels were Level I (non-resource based), Level II (skill-based), Level III (strategy-based), and Level IV (consultation). For each level of question, a definition and series of questions was provided to help reference librarians and paraprofessionals recognize the level to which a particular question belonged. ${ }^{12}$

The Warner model showed the greatest promise for collecting useful data that could be used in the assignment of the appropriate mix of librarians and staff to in-person, telephone, e-mail, and live online reference services. Our article reports on the application of the Warner model in the MLK Library Reference unit and how activity count results were used to adjust staffing levels, change the service point configuration, and improve the tiered reference model. The Warner model was adopted as the most potentially useful method to count in 
a more sophisticated way all the questions asked in the building.

\section{REFERENCE SERVICES}

The impetus behind the merger of reference includes both a desire to achieve staff economies and a commitment to strengthen the mission to provide opportunities for lifelong learning. Planning for the merger of SJSU's and the SJPL's separate reference departments began in fall 2002 with the creation of planning teams charged with developing policies and procedures in specific function or service areas, including assessment, reference collection development, electronic resources, email reference, information literacy, reference, information desk, telephone reference, training, and virtual reference. These cross-organizational teams also served as a means for the public and academic staffs to begin working together through a shared discussion list, a "library buddies" program, and team-oriented meetings. Conforming to the dictates of the Memorandum of Understanding between the SJPL and the University Library of SJSU, staffing of the reference desk was to be achieved through an equal division of staff hours. ${ }^{13}$ This was interpreted to mean that usually one academic and one public librarian would work at the desk together in a "seamless" way.

The idea of "seamless" service was that SJSU students or public customers would receive highquality reference assistance regardless of the affiliation (academic or public) of the person assisting them. Patrons who needed more help than the desk staff could provide would be referred to a subject specialist. Formal staff training and informal and collegial consultation and mentoring increased the skill levels of all librarians. Generally speaking, the merged units in the new library (e.g., Circulation and Reference) work together with as little staff differentiation as possible in the delivery of customer service.

Upon opening in 2003, the reference desk was located at the north end of the second floor, a general information desk was on the first floor, and the SJPI's general collection desk was on the third floor. The reference desk was configured to provide four workstations serving walk-in patrons. Distance services-telephone reference, e-mail, live online reference-were provided by librarians working in a separate room called the Reference Connection.

\section{DATA COLLECTION}

Data collection at the MLK Library began in September 2003, one month after the library opened. Each service point within the library collected data during survey weeks using the Service Point Activity Count forms (see appendix). The two forms, one for in-person and one for remote (e.g., telephone and e-mail), were used at all six public service points in the nine-floor facility: the information desk and the circulation desk (first floor), the reference desk (second floor), the general collections desk (third floor), the periodicals desk (fourth floor), and the Cultural Heritage Center desk (fifth floor). For one week in each month, hourly data was gathered. During the initial year of operation from September 2003 through June 2004 , only the Reference unit distinguished the levels of questions as Levels I-IV.

Beginning in July 2004, all public service points began to categorize and record questions using the Warner model. The 45 percent variation in the classification of questions noted by Kesselman and Watstein prompted MLK Library planners to add sample questions and definitions on the survey forms. ${ }^{14}$ Data thus collected could be used to increase service efficiency and to inform decisions on staffing of service desks. The remainder of this article deals specifically with the data collected within the Reference unit and what it indicates about the ability to fulfill patron needs.

\section{RESULTS}

Analysis of data for the Reference unit falls into four sections: initial period (September 2003 to February 2005), combined telephone and reference (March to September 2005), in-service (June 2005), and the post-in-service experience (October 2005 to May 2006), as reflected in tables $1-5$ and figures 1-3. These four sections reflect MLK Library's attempt to analyze operations, more efficiently allocate librarians and staff, apply the Warner model to a different type of library, and begin to address the needs of new technologies.

\section{Initial Period: September 2003 to February 2005}

Table 1 shows the initial use of the Warner model in identifying Level I-IV questions received at the reference desk and in the Reference Connection room.

The data reflect both in-person and telephone questions answered by librarians, support staff, and student assistants. During this period, 100 percent of telephone reference questions were answered by librarians in the Reference Connection room.

The results demonstrate that the percentage of Level I-II questions versus Level III-IV questions handled were consistent with the 80 percent-20 
Table 1. Reference Desk Questions, September 2003-February 2005

\begin{tabular}{|c|c|c|c|c|c|}
\hline Month & $\begin{array}{c}\text { Total } \\
\text { Reference } \\
\text { Questions }\end{array}$ & $\begin{array}{c}\text { Nonresource- } \\
\text { Based/Tier } 1\end{array}$ & $\begin{array}{c}\text { Skill-Based/ } \\
\text { Tier2 }\end{array}$ & $\%$ Tier $1+2$ & $\begin{array}{c}\% \text { Tier } 1+2 \\
\text { Answered by } \\
\text { Librarians }\end{array}$ \\
\hline September 2003 & 3484 & 1862 & 1284 & 90 & 63 \\
\hline October 2003 & 3192 & 1381 & 1118 & 78 & 61 \\
\hline November 2003 & 2974 & 1347 & 912 & 76 & 59 \\
\hline December 2003 & 2526 & 1204 & 815 & 80 & 62 \\
\hline January 2004 & 1974 & 932 & 646 & 80 & 69 \\
\hline February 2004 & 2935 & 1461 & 943 & 82 & 62 \\
\hline March 2004 & 2927 & 1202 & 1026 & 76 & 61 \\
\hline April 2004 & 2642 & 1058 & 877 & 73 & 60 \\
\hline May 2004 & 2770 & 1130 & 922 & 74 & 63 \\
\hline June 2004 & 1683 & 702 & 590 & 77 & 78 \\
\hline July 2004 & 2021 & 829 & 786 & 80 & 71 \\
\hline August 2004 & 1429 & 567 & 498 & 75 & 66 \\
\hline September 2004 & 2798 & 1187 & 943 & 76 & 60 \\
\hline October 2004 & 2271 & 916 & 669 & 70 & 54 \\
\hline November 2004 & 2445 & 900 & 837 & 71 & 58 \\
\hline December 2004 & 2198 & 859 & 691 & 71 & 61 \\
\hline January 2005 & 1686 & 660 & 640 & 77 & 69 \\
\hline February 2005 & 2485 & 1091 & 851 & 78 & 59 \\
\hline
\end{tabular}

percent pattern established by Warner. Baseline use figures for both semesters and break periods were established for the total number of questions received. While the total number of reference questions has remained high, more Level III-IV questions were addressed during the fall and spring semesters than during winter or summer breaks (e.g., January, June, July, and August).

Because of the library's goal to implement tiered reference, one area of special interest was the number of lower-level questions answered by librarians rather than support staff or student assistants. With this percentage consistently near or over 60 percent and sometimes nearing 80 percent, the survey data was examined more closely for periods of low question volume, particularly for telephone reference that was handled by librarians in the Reference Connection room. It was felt that, with librarians answering 100 percent of the telephone reference questions, the number of lower-level telephone questions could be easily reassigned to support staff.

\section{Combined Telephone and Reference: March to September 2005}

As a result of the examination of the data, the separately scheduled telephone reference service was moved out to the reference desk from 9-10 a.m. (Monday-Friday) and from 5-9 p.m. (MondayThursday). In this new service model, support staff and student assistants answered the telephone first, fielding Level I-II questions, and referring Level III-IV questions to librarians at the desk.

The data reflecting the combination of telephone reference with in-person reference during limited hours can be seen in table 2. While the percentage remained fairly constant for Level I-II questions, the percentage answered by librarians dropped below 60 percent, and the usage of li- 
Table 2. In-person and Limited Telephone Service at Reference Desk, March 2005-September 2005

\begin{tabular}{|c|c|c|c|c|c|}
\hline Month & $\begin{array}{c}\text { Total } \\
\text { Reference } \\
\text { Questions }\end{array}$ & $\begin{array}{c}\text { Nonresource- } \\
\text { Based/Tier } 1\end{array}$ & $\begin{array}{c}\text { Skill-Based/ } \\
\text { Tier2 }\end{array}$ & $\%$ Tier $1+2$ & $\begin{array}{c}\% \text { Tier } 1+2 \\
\text { Answered by } \\
\text { Librarians }\end{array}$ \\
\hline March & 2570 & 1073 & 867 & 75 & 48 \\
\hline April & 2174 & 878 & 784 & 76 & 54 \\
\hline May & 2001 & 678 & 668 & 67 & 53 \\
\hline June & 1197 & 497 & 397 & 75 & 55 \\
\hline July & 1364 & 541 & 509 & 77 & 57 \\
\hline August & 1140 & 468 & 462 & 82 & 57 \\
\hline September & 2374 & 992 & 852 & 78 & 50 \\
\hline
\end{tabular}

brarian time at the reference desk was reduced by 20 percent. The change in telephone service also reduced the percentage of telephone questions answered by librarians from the 100 percent experienced before March 2005 to an average of 86 percent. A small function and staffing change had a greater effect than expected.

\section{In-service: June 2005}

The SJPL has had a tradition of holding in-service events for training and other purposes. In June 2005, the entire Reference unit devoted its inservice to the evaluation of tiered reference service. Librarians and support staff from the public library's General Collections unit joined the librarians and staff of the Reference unit to share their collective experience with the data-gathering process. To ensure that everyone understood the Warner model, definitions and examples of Level I-IV questions were reviewed. The forty-five librarians, support staff, pages, and student assistants in attendance were asked to assign fifty-five questions (e.g. "My laptop doesn't connect," "I need a video on exporting. How do I find one?" "Can I reserve a room for my group's meeting next week?" and "I need some information on the German court system") to Level I, II, III, or IV on the basis of examples used on the Individual Activity Count form. Small breakout groups discussed the coding and reported their results to the larger group, with an overall agreement rate of 69 percent.

Table 3 shows the nine questions that generated the most confusion. Seven of the questions reflected the difficulties encountered in identifying Level II-III questions. An analysis of the results found that some librarians and staff had coded questions on the basis of their personal knowledge of the subject or the answer rather than on the level of the question. This result is similar to results found by Kesselman in which personnel used their own definitions when tallying reference questions by category. ${ }^{15}$ Based on the in-service experience, the examples for the Level I-II questions were modified for subsequent survey periods (see table 4) in hopes of avoiding future confusion about categorizing questions. The revised form was distributed to all library units that participated in the survey week each month.

\section{Post-In-Service Period: October 2005 to May 2006}

Because of the data reported in tables 1 and 2 and the in-service experience (tables 3 and 4), the Reference unit decided to pursue four goals: better triage of questions, ability to handle more telephone calls, use of librarian time for more complicated questions, and the potential for staff adjustments. To accomplish these goals, the telephone reference service was fully combined with the in-person reference service in October 2005.

In October 2005, reference desk staffing consisted of two librarians and a support staff person or student assistant. The support staff or student assistant welcomed new patrons, answered their simple directional, technical, or catalog-search questions, and directed those with complicated questions to librarians. A modest redesign of the reference desk was done to facilitate the triage of telephone questions. A wall of paneling was added to a section of the reference desk to discourage in-person questions at that location. The librarians scheduled for telephone reference moved 
Table 3. In-Service Question Problems

\begin{tabular}{|c|c|c|c|}
\hline $\begin{array}{l}\text { Question } \\
\text { Number }\end{array}$ & Problem Question & $\begin{array}{l}\text { \% Identified as } \\
\text { Level } 2\end{array}$ & $\begin{array}{l}\% \text { Identified as } \\
\text { Level } 3\end{array}$ \\
\hline 1 & $\begin{array}{l}\text { How do I access journal articles in Expanded } \\
\text { Academic Index? }\end{array}$ & 68 & 24 \\
\hline 17 & $\begin{array}{l}\text { I am trying to locate Japanese Marauding in Medi- } \\
\text { eval Korea. Unpublished PhD Thesis, University } \\
\text { of California, Berkeley, 1967. It is in your library } \\
\text { system, but under status as "missing." What are } \\
\text { my chances of locating this? }\end{array}$ & 44 & 47 \\
\hline 21 & I need a video on exporting. How do I find one? & 55 & 33 \\
\hline 43 & Where can I get a list of businesses in San Jose? & 22 & 49 \\
\hline 49 & $\begin{array}{l}\text { I need the GDP for several countries from } 1990 \\
\text { to the present. }\end{array}$ & 15 & 55 \\
\hline 52 & I need books on Mexican folklore. & 42 & 33 \\
\hline 54 & How do I cite these in MLA style? & 49 & 29 \\
\hline $\begin{array}{l}\text { Question } \\
\text { Number }\end{array}$ & Problem Question & $\begin{array}{l}\% \text { Identified as } \\
\text { Level } 3\end{array}$ & $\begin{array}{l}\text { \% Identified as } \\
\text { Level } 4\end{array}$ \\
\hline 5 & $\begin{array}{l}\text { I have an American Studies class, "American } \\
\text { Dream," this semester. I am writing a term paper } \\
\text { on the business, residential, and political history, } \\
\text { including interviews with residents, politicians, } \\
\text { and business owners in my Fremont neighbor- } \\
\text { hood of "Little Kabul." Where would you suggest } \\
\text { I find records, archives, and maps for this paper? }\end{array}$ & 22 & 62 \\
\hline 11 & $\begin{array}{l}\text { I am researching the Pao Hua Buddhist temple } \\
\text { on McKee Road. I need to find the history, prop- } \\
\text { erty, land, and what makes it powerful. }\end{array}$ & 49 & 44 \\
\hline
\end{tabular}

Table 4. Level I and II Question Category Examples

\begin{tabular}{|c|c|c|}
\hline & Examples Used Before June 2005 & $\begin{array}{l}\text { Examples Used After } \\
\text { June } 2005\end{array}$ \\
\hline \multirow[t]{3}{*}{ Level 1 Questions } & Where are the copy machines? & Where are the copy machines? \\
\hline & How late are you open on Friday? & How late are you open on Friday? \\
\hline & Do you have today's newspaper? & Where is the California Room? \\
\hline \multirow[t]{5}{*}{ Level 2 Questions } & How do I download to a floppy? & How do I add money to my Tower Card? \\
\hline & $\begin{array}{l}\text { How can I access your database over the } \\
\text { Internet from home? }\end{array}$ & How do I print my resume? \\
\hline & Where do I find this call number? & Do you have any books by this author? \\
\hline & How do I print from Netscape? & $\begin{array}{l}\text { How can I access the databases from } \\
\text { home? }\end{array}$ \\
\hline & How can I find a video in your catalog? & How can I find a DVD in your catalog? \\
\hline
\end{tabular}


Table 5. Fully Merged In-person and Telephone Service at the Reference Desk, October 2005-May 2006

\begin{tabular}{|c|c|c|c|c|c|}
\hline Month & $\begin{array}{c}\text { Total } \\
\text { Reference } \\
\text { Questions }\end{array}$ & $\begin{array}{c}\text { Nonresource- } \\
\text { Based/Tier } 1\end{array}$ & $\begin{array}{c}\text { Skill-Based/ } \\
\text { Tier2 }\end{array}$ & $\%$ Tier $1+2$ & $\begin{array}{c}\% \text { Tier } 1+2 \\
\text { Answered by } \\
\text { Librarians }\end{array}$ \\
\hline October 2005 & 2073 & 842 & 796 & 79 & 34 \\
\hline November 2005 & 1913 & 762 & 646 & 74 & 36 \\
\hline December 2005 & 1708 & 767 & 596 & 80 & 40 \\
\hline January 2006 & 1200 & 535 & 438 & 81 & 48 \\
\hline February 2006 & 1817 & 748 & 651 & 77 & 46 \\
\hline March 2006 & 1980 & 842 & 738 & 80 & 37 \\
\hline April 2006 & 1885 & 713 & 679 & 74 & 37 \\
\hline May 2006 & 1651 & 695 & 579 & 77 & 39 \\
\hline
\end{tabular}

Figure 1. Telephone Reference Questions, Oct. 2005-May 2006

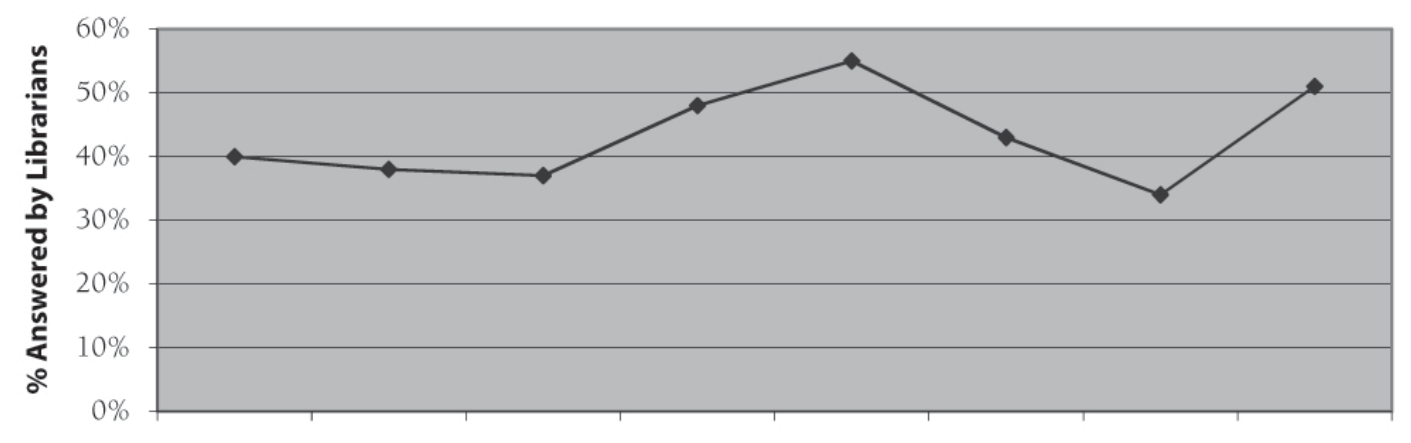

October 2005-May 2006

there, with a support staff or student assistant added during the busiest hours. The support staff or student assistant would answer the telephone first and forward more difficult questions to the designated librarian.

Table 5 and figure 1 show the results of these changes. Table 5, a continuation of the data reported in tables 1 and 2 , shows a reduction of 35 percent in the number of questions received between October 2005 and May 2006 when compared with the library's inaugural year (October 2003 to May 2004) and a reduction of 20 percent when compared with October 2004 to May 2005. While the percentage of Level I-II questions remains high (74-81 percent), the percentage of the lower-level questions answered by librarians was reduced significantly from the $60-80$ percent to 34-48 percent. The changes resulted in increased opportunities for better triage of reference questions and more effective use of librarian time.

Figure 1 shows that librarians answered an average of 43 percent of Level I-II telephone reference questions between October 2005 and May 2006. This is a significant reduction from the 100 percent of telephone reference questions answered by librarians from September 2003 through early 2005 and the 86 percent answered by librarians from early 2005 to October 2005. The staffing and service adjustments that have been made have had a positive effect on question triage and the effective use of staff.

The categories defined in the Warner model were also used to categorize e-mail and virtual reference questions. At the MLK Library, the responsibility for e-mail reference service is shared equally by academic and public librarians. Figure 2 shows 
Figure 2. E-mail Reference Questions

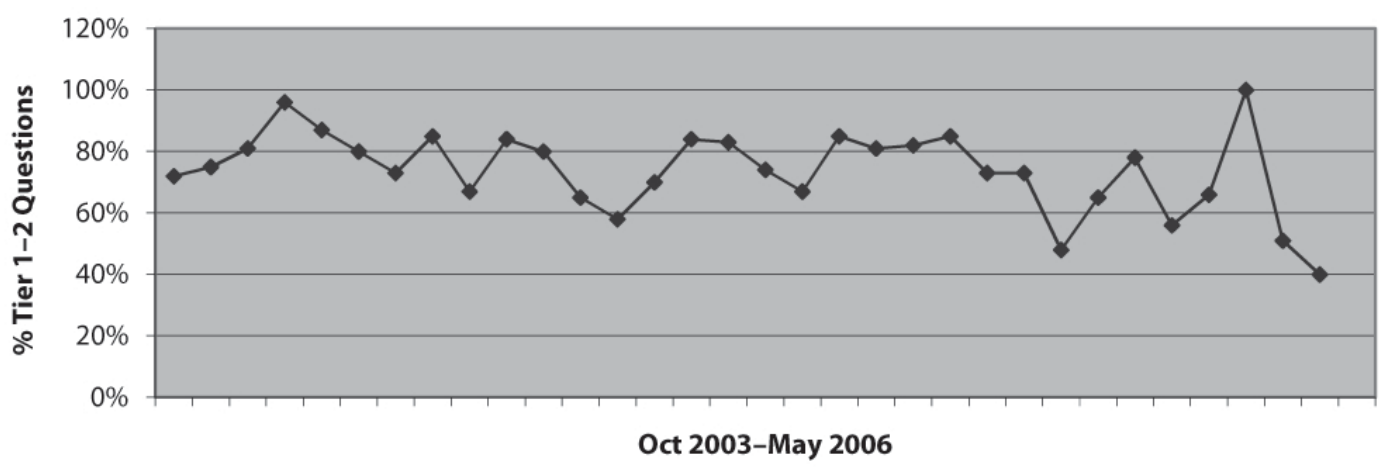

the percentage of Level I-II e-mail questions from October 2003 through May 2006. The results are similar to the percentage of Level I-II questions received for in-person activity. The total number of e-mail questions received per month (16-118) fluctuates, but is higher in the months at the beginning of a semester, such as September-October and February-March (85-119 questions). Over the thirty-month period, the number of Level I-II questions dipped below 70 percent only five times and below 60 percent only once. The data show that the Warner model applies to e-mail reference and suggest that the merged library should examine an approach to e-mail reference that employs support staff in handling more basic questions.

Live online reference is not a merged function. SJPL librarians monitor a public library queue while SJSU librarians monitor a California State University system queue. With data only available for selected months for the public library queue and comparable data not available for the academic queue, it is impossible to draw conclusions about the effectiveness of the Warner model for evaluating live online reference.

The data that is available suggests that the pattern for virtual online reference questions is the opposite of that reported for in-person, telephone, and e-mail reference. With a lower percentage of Level I-II questions (less than 50-60 percent), it appears that more complex questions are received through virtual reference than through in-person, telephone, or e-mail reference. This experience suggests that the Warner model and categories could apply to newer forms of reference service (e.g., instant messaging and text messaging) and requires further study. DeGroote's study on centralizing digital reference service for multiple locations and establishing benchmarks is an example of a possible future research direction. ${ }^{16}$
Data gathered from fall 2005 was compared with data from fall 2006 to determine trends in the following two areas: the recorded level of business and the effect of telephone questions. A reduction in the number of reference questions following the fall 2003 opening of the library was expected, since both Balas and DeGroote reported declining levels of questions since the 1990s while ARL libraries reported a 34 percent reduction. ${ }^{17}$ MLK Library reference data suggests that not only has the reduction leveled off, but that the number of in-person questions is rising during peak semester months. Table 6 shows that the total number of in-person and telephone reference questions (7460) is similar to the number recorded in fall 2005 (8068), with only a 7 percent reduction.

This is good news, since fall 2005 data had shown a 16 percent reduction from 2004 use figures (9712). Only December 2006 shows fewer overall questions, particularly in Level I questions, a reduction of over 20 percent when compared to December 2005. The number of in-person queries was up slightly in October and November 2006 (4 percent and 6 percent, respectively). Figure 3 shows that the ratio of Level I-II questions to Level III-IV questions remained consistent, but that the percentage of telephone reference questions shrank from 18-23 percent to 14-16 percent.

\section{DISCUSSION AND CONCLUSIONS}

The Warner model was devised to support and plan the transition from a dual-desk setup to a onedesk setup in a health sciences library. It clearly applies to other reference operations and types of libraries. The adaptation of the Warner model at the MLK Library confirms that the definition of questions by level, with each level requiring more 
Table 6. Comparison of Reference Desk Questions, Fall 2005 and Fall 2006

\begin{tabular}{|c|c|c|c|c|c|}
\hline Month & $\begin{array}{c}\text { Total } \\
\text { Reference } \\
\text { Questions }\end{array}$ & $\begin{array}{c}\text { Non- } \\
\text { resource- } \\
\text { Based-Tier } 1\end{array}$ & $\begin{array}{c}\text { Skill-Based- } \\
\text { Tier2 }\end{array}$ & \% Tier $1+2$ & $\begin{array}{l}\text { \% Phone } \\
\text { Questions }\end{array}$ \\
\hline September 2005 & 2374 & 992 & 852 & 78 & 14 \\
\hline September 2006 & 2306 & 986 & 805 & 77 & 14 \\
\hline October 2005 & 2073 & 842 & 796 & 79 & 22 \\
\hline October 2006 & 2017 & 816 & 717 & 76 & 16 \\
\hline November 2005 & 1913 & 762 & 646 & 74 & 23 \\
\hline November 2006 & 1835 & 707 & 646 & 73 & 14 \\
\hline December 2005 & 1708 & 767 & 596 & 80 & 18 \\
\hline December 2006 & 1302 & 533 & 464 & 76 & 15 \\
\hline
\end{tabular}

Figure 3. Comparison of Reference Desk Questions, Fall 2005 and Fall 2006

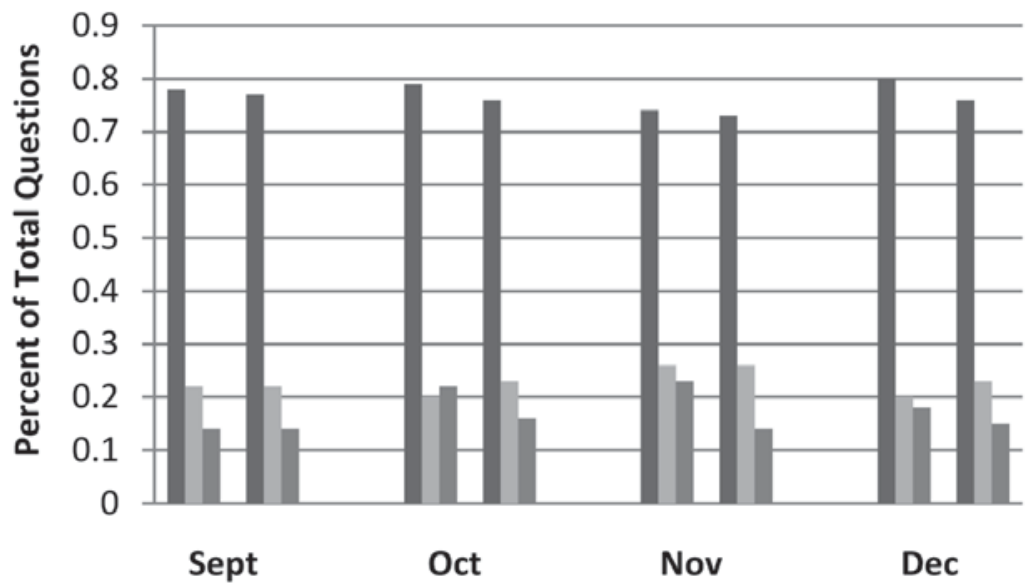

$\%$ Tier $1+2$

\% Tier $3+4$

$\%$ Phone Ques.

sophisticated methods for answering them, is appropriate to the MLK Library and would be useful in almost any library. The examples used for assigning questions to a level can be customized to reflect the type of library or clientele. ${ }^{18}$

The Warner model provides an effective way of evaluating the effectiveness of services because it provides a method for counting questions by difficulty and determining who can best answer them. It has also led to the increased efficiency of the reference desk, a successful tiered integration of librarians, library staff, and student assistants, all of whom utilize the same method of evaluating and answering questions. And this has, in turn, informed adjustments in optimal staffing levels. Future research can take a look at the question evaluation and staffing data in the context of determining if the Warner model has also led to better service for patrons, but this is beyond the scope of this article.

Librarians and support staff may require additional training in differentiating Level I-II and Level III-IV questions. In August-September 2005, student assistants and support staff received special training in tiered reference and the recognition of Level I-II questions. This training resulted in greater accuracy and consistency in the coding. The training of librarians and staff in the question levels and their participation in the ongoing definition and coding of questions can only help to make the ongoing evaluation of services more effective. 
The MLK Library in-service, during which personnel from General Collections participated along with Reference personnel in a coding exercise, demonstrates that what has been learned at the reference desk can be applied to other service points for a greater consistency and accuracy building-wide. The experience at the MLK Library and in the library literature shows that training, particularly of paraprofessionals, is the key to maintaining quality of service and to reducing the number of situations in which the paraprofessional has to decide the category of a query "in the absence of detailed guidelines and without a chance to consult a professional."19

The general ratio of 80-20 between the numbers of simpler (Levels I-II) and more complicated (Levels III-IV) questions found by Warner holds true in other libraries. Further testing would be needed to determine if it remains a constant for all reference services. This validates the Warner study and indicates its overall appropriateness for libraries of various kinds.

The goal of tiered reference is to maximize the skills of librarians and support staff by using the appropriate level of staff to answer different levels of questions. In the MLK Library, the information desk is centrally located on the first floor of the library. It was originally hypothesized that the information desk would siphon off all the Level I-II questions, leaving the rest to be handled by the reference desk on the second floor or the general collections desk on the third floor. This did not happen. Given the complexity of a nine-story library building, library patrons go to the nearest service desk to ask questions. The library as a whole, however, is working to achieve greater coordination by creating cross-training modules involving these different units.

Within the context of the Reference unit, the assignment of librarians to answer phones as their primary duty was changed to answering the Level III-IV questions referred to them by paraprofessionals or student assistants. The change in staffing also provided more desk support for those times when there was greater demand from patrons for assistance. Closer analysis of data by hour of the day could further fine-tune staffing decisions. Such analysis could identify times and days within specific months when the demand for librarians to answer Level III-IV questions is highest.

In addition, other factors will have to be considered in the application of the Warner modelthe time it takes to answer reference questions, the differing conditions in libraries that are highly multicultural, and the consistuency that each library serves (health science, university, K-12, public, etc.). Inclusion of such factors in future research will certainly lead to the refinement of the Warner model.

The Warner model was adopted in the early part of the planning process that led to the establishment of this joint public and university library reference service (one aspect of the merged MLK Library). It defined the ongoing development of the reference service and helped to create a context in which public and university librarians and staff could work together to respond effectively to the needs of all patrons. It showed that there is definite overlap in the kind of information demanded by university and public patrons and aided in the achievement of efficiencies in staffing and training within the merged reference unit. It will provide a basis for the ongoing evolution and improvement of reference service in the MLK joint-use library.

\section{References and Notes}

1. The website for the MLK Library is at http://sjlibrary. org; Peggy Conaway, "One Reference Service for Everyone?" Library Journal 125, no. 12 (July 2000): 42-44; Paul Kauppila and Sharon Russell, "Economies of Scale in the Library World: The Dr. Martin Luther King, Jr. Library in San Jose, California," New Library World 104, no. 7/8 (2003): 255-66; Christina Peterson and Patricia Senn Breivik, "Reaching for a Vision: The Creation of a New Library Collaborative," Resource Sharing \& Information Networks 15, no. 1-2 (2001): 117-29.

2. Christina Peterson, "A Space Designed for Lifelong Learning: The Dr. Martin Luther King, Jr. Joint-Use Library," Library as Place: Rethinking Roles, Rethinking Space (Washington, D.C.: Council on Library and Information Resources, 2005): 56-65; Harry Meserve, "Evolving Reference, Changing Culture: The Dr. Martin Luther King, Jr. Library and Reference Challenges Ahead," The Reference Librarian 45, no. 93 (2006): 23-42.

3. Lauren Miranda Gilbert et al., "Assessing Digital Reference and Online Instructional Services in an Integrated Public/University Library," The Reference Librarian 46, no. 95/96 (2006): 149-72.

4. The Evaluation of Reference \& Adult Services Committee, ed., The Reference Assessment Manual (Ann Arbor, Mich.: The Pierian Press, 1995).

5. Paul B. Kantor, "Analyzing the Availability of Reference Services," Library Effectiveness: A State of the Art (New York: ALA, Library and Management Association, 1980), 131-49; Jo Bell Whitlatch, "Unobtrusive Studies and the Quality of Academic Library Reference Services," College \& Research Libraries 50, no. 1 (Mar. 1989): 181-94; Russell F. Dennison, "UsageBased Staffing of the Reference Desk: A Statistical Approach," Reference \& User Services Quarterly 39, no. 2 (Winter 1999): 158-68; Sandra L. DeGroote et al., "Quantifying Cooperation: Collaborative Digital Reference Service in a Large Academic Library," College E Research Libraries 66, no. 5 (Sept. 2005): 436-54; Vicki Coleman et al., "Tiered Reference Services: A Survey," The Reference Librarian 59 (1997): 25-35; 
Marcella Ciucki, "Recording of Reference/Information Service Activities: A Study of Forms Currently Used," RQ 16 (Summer 1977): 273-83.

6. Douglas L. Zweizig, "Tailoring Measures to Fit Your Service: A Guide for the Manager of Reference Services," The Reference Librarian 11 (1984): 53-61; Coleman, "Tiered Reference Services"; Martin P. Courtois and Lori I. Goetsch, "Use of Nonprofessionals at Reference Desks," College \& Research Libraries 45, no. 5 (Sept. 1984): 385-91; Marjorie E. Murfin and Charles A. Bunge, "Paraprofessionals at the Reference Desk," Journal of Academic Librarianship 14, no. 1 (Mar. 1988): 10-14.

7. Jo Bell Whitlatch, "Question Classification," in The Reference Assessment Manual, ed. the Evaluation of Reference \& Adult Services Committee (Ann Arbor, Mich.: The Pierian Press, 1995): 42-46.

8. Eric Novotny, Reference Service Statistics \& Assessment: A SPEC Kit. (Washington, D.C.: Association of Research Libraries, 2002).

9. Ciucki, "Recording of Reference/Information Service Activities."

10. Courtois, "Use of Nonprofessionals at Reference Desks," 388.

11. Murfin and Bunge, "Paraprofessionals at the Reference Desk." See also more recent studies on the same questions such as Jeffrey Pomerantz et al., "Peer Review of Chat Reference Transcripts," Library \& Information Science Research 28, no. 1 (2006): 24-48; Frada Mozenter et al., "Cross-training Public Service Staff in the Electronic Age," Journal of Academic Librarianship 29, no. 6 (Nov. 2003): 399-404; and Soo Young
Rieh, "Changing Reference Service Environment: A Review of Perspectives from Managers, Librarians, and Users," Journal of Academic Librarianship 25, no. 3 (May 1999): 178-86.

12. Debra G. Warner, "A New Classification for Reference Statistics," Reference \& User Services Quarterly 41 (Fall 2001): 51-55.

13. See the Agreement for Ownership and Operation of Joint Library Building and Grant of Easement at www.sjlibrary.org/about/locations/king/operating_ agreement.pdf along with a time line of the progress of the library project at www.sjlibrary.org/about/history/timeline.htm.

14. Martin Kesselman and Sarah Barbara Watstein, "The Measurement of Reference and Information Services," Journal of Academic Librarianship 13, no. 1 (Mar. 1987): 24-30.

15. Ibid.

16. DeGroote, "Quantifying Cooperation."

17. Janet L. Balas, "It's Time to Prove Our Mettle," Computers in Libraries 24, no. 5 (May 2004): 33-35; Sandra DeGroote et al., "Trends in Reference Usage Statistics in an Academic Health Sciences Library," Journal of the Medical Library Association 95, no. 1 (Jan. 2007): 23-30; Susan Gardner, "Tiered Reference: The New Landscape of the Front Lines," Electronic Journal of Academic and Special Librarianship 7, no. 3 (Winter 2006).

18. Ciucki, "Recording of Reference/Information Service Activities."

19. Courtois, "Use of Nonprofessionals at Reference Desks," 389.

\section{WHO LET THE LIBRARIANS OUT? CONTINUED FROM PAGE 242}

2. Susan Sharpless Smith and Lynn Sutton, "Embedded Librarians: On the Road in the Deep South," College $\mathcal{E}$ Research Libraries News 69, no. 2 (Feb. 2008): 71-74, 85.

3. Deborah Brown and Dean Leith, "Integration of the Research Library Service into the Editorial Process," Aslib Proceedings: New Information Perspective 59, no. 6 (2007): 539-49.

4. Michael F. Moore, "Embedded in Systems Engineering: How One Organization Makes It Work," Information Outlook 10, no. 5 (May 2006): 23-25.

5. Angela M. Tod et al., "Exploring the Contribution of the Clinical Librarian to Facilitating Evidence-Based Nursing," Journal of Clinical Nursing 16, no. 4 (2007): 621-29.
6. E. Stewart Saunders, "The LibQUAL+ Phenomenon: Who Judges Quality?" Reference E User Services Quarterly 47, no. 1 (Fall 2007): 21-24.

7. Reference and User Services Association, "Guidelines for Liaison Work in Managing Collections and Services," www.ala.org/ala/mgrps/divs/rusa/ archive/protools/referenceguide/guidelinesliaison .cfm (accessed Aug. 29, 2008).

8. John Rodwell and Linden Fairbairn, "Dangerous Liaisons? Defining the Faculty Liaison Librarian Service Model, Its Effectiveness and Sustainability," Library Management 29, no. 1/2 (2008): 116-24.

9. Stacy L. Voeller, "Brazelton Encourages Librarians To Be Part of the Family," Cognotes 4 (2008): 6. 
APPENDIX. SERVICE POINT ACTIVITY COUNT FORM
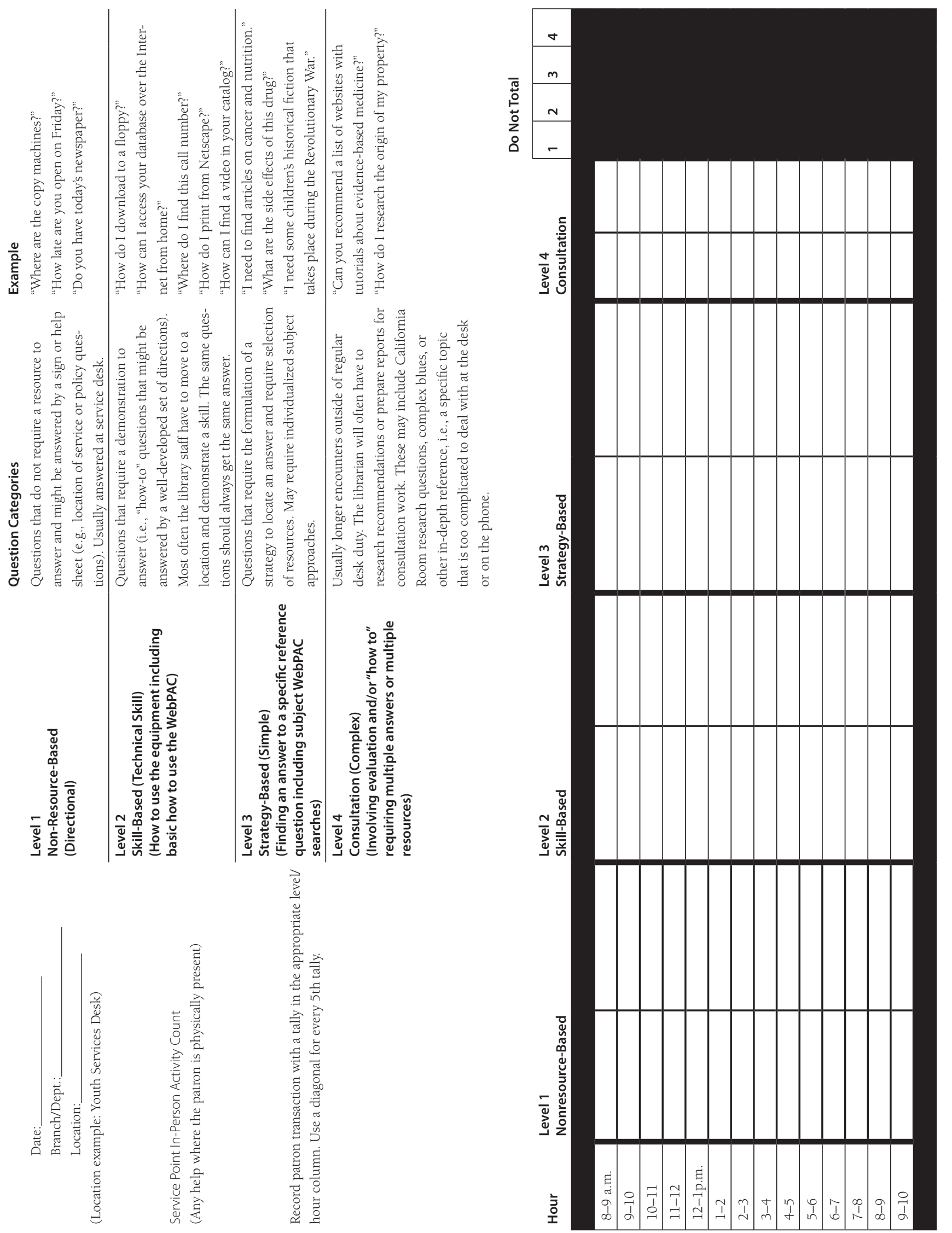